НАУКОВИЙ ВІСНИК

Ventife messenger of L Liv National University of

(1)

TIMT

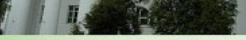

(D) SERES-AGRicuLtuRAL SCIEN

$$
2020
$$

Науковий вісник Аьвівського національного університету ветеринарної медицини та біотехнологій імені С.3. Гжицького. Серія: Сільськогосподарські науки

Scientific Messenger of Lviv National University of Veterinary Medicine and Biotechnologies. Series: Agricultural sciences

UDC 636.087.8:636.033

\title{
Productivity of pigs when feeding celluloseamylolytic additive
}

\author{
V. Y. Novakovska \\ Institute of Feed and Agriculture of Podillya NAAS, Vinnytsia, Ukraine
}

Article info

Received 10.02.2020

Received in revised form 12.03.2020

Accepted 13.03.2020

Institute of Feed and Agriculture of Podillya NAAS, Prospect Youth, 16, Vinnytsia, 21100, Ukraine. Tel: $+38-097-932-06-91$ Email:novavy27@gmail.com
Novakovska, V. Y. (2020). Productivity of pigs when feeding celluloseamylolytic additive. Scientific Messenger of Lviv National University of Veterinary Medicine and Biotechnologies. Series: Agricultural sciences, 22(92), 76-80. doi: 10.32718/nvlvet-a9213

The use of different feed processing methods using exogenous feed additives to improve the digestibility of plant feed ingredients in pig feeding has been studied for decades. In the research laboratory of the Institute of Forage and Agriculture of Podillya NAAS, compositions of enzymes with cellulase and amylase activity were studied. They are able to effectively break down non-starch polysaccharides in cereals, increase digestibility and absorption of feed nutrients. The purpose of this work was to study the zootechnical efficiency of the use of biologically active in the composition of feed pigs for fattening. In the presented material, the influence of feeding cellulose amylolytic enzyme additive on the productive qualities of pigs for fattening is highlighted. The cellulose amylolytic additive contained $\alpha$-amylase with an activity of $9342 \mathrm{IU} / \mathrm{h}$ and cellulase with an activity of $540 \mathrm{IU} / \mathrm{h}$. Studies in pigs were performed in two stages: the equalization period (15 days) and the main ( 71 days). For feeding pigs, a feed mixture was used, consisting of feed grown directly on the farm-barley, wheat, soybeans. The diet of the control group consisted of $63 \%$ barley grain, $27.5 \%$ wheat grain, $9 \%$ soybean meal $0.5 \%$ mineral supplement. Pigs of the experimental group were fed cellulose amylolytic feed additive at the rate of $5 \mathrm{~g}$ of cellulase and $1 \mathrm{~g}$ of amylase per $1 \mathrm{~kg}$ of feed. Feeding supplements determines the intensity of the process of digestion of proteins, fats and carbohydrates. Cellulose-amylolytic additive affects the absorption of carbohydrates in the diet, providing an increase in the digestibility of the control and experimental groups, respectively, neutral-detergent fiber (38.2 and $46.7 \%$ ), acid-detergent fiber (18.7 and $36.5 \%)$, the amount easily hydrolyzed carbohydrates (85.4 and $90.2 \%$ ), hemicellulose (65.7 and $61.5 \%)$, cellulose (13.2 and $21.4 \%)$. The decision on the feasibility of including celluloseamylolytic additive in the diet can be confirmed on the basis of its use during the scientific and economic experiment. In the control group, the average daily increase in live weight was $725.07 \mathrm{~g}$, and in the experimental group by $19.7 \%$ more at the level of $902.53 \mathrm{~g}$. It was also noted a positive effect on the formation of body biomass, development of individual organs and their systems.

Key words: pigs, enzymes, cellulase, amylase, digestibility of nutrients, growth intensity, productivity.

\section{Продуктивність свиней при згодовуванні целюлозоамілолітичної добавки}

\author{
В. Ю. Новаковська
}

Інститут кормів та сільського господарства Поділля Національної академії аграрних наук України, м. Вінниия, Украӥна

Застосування різних методів переробки кормів за використання екзогенних кормових добавок для покращення засвоюваності рослинних кормових інгредієнтів у годівлі свиней вивчається десятиліттями. У дослідницькій лабораторї Інституту кормів та сільського господарства Поділля НААН досліджено композиції ензимів, ияо володіють ичелюлазною й амілазною активністю. Вони здатні ефективно розщеплювати некрохмальні полісахариди зернових культур, підвищувати перетравність $і$ засвоєння поживних речовин кормів. Метою даної роботи було вивчити зоотехнічну ефективність застосування біологічно активних у складі комбікормів свиней на відгодівлі. У представленому матеріалі, висвітлено вплив згодовування целюлозоамілолітичної ферментної добавки на продуктивні якості свиней на відгодівлі. Целюлозоамілолітична добавка містила у своєму складі а-амілазу з активністю 9342 од/год та иелюлазу з активністю 540 од/год. Дослідження на свинях проводили у два етапи: зрівняльний період (15 діб) та 
основний (71 діб). Для годівлі свиней було використано кормосуміш, щуо складається з кормів вирощених безпосередньо у господарстві - зерно ячменю, пшениці, сої. Раціон контрольної групи складався з 63 \% зерна ячменю, 27,5\% зерна пиениці, 9 \% макухи соєвої 0,5 \% мінеральної добавки. Свиням дослідної групи згодовували целюлозоамілолітичну кормову добавку в розрахунку 5 г целюлази і 1 г амілази на 1 кг корму. Згодовування добавки зумовлює інтенсивність прочесу перетравлення білків, жсиів, вуглеводів. Целюлозоамілолітична добавка впливає на засвоєння вуглеводів у раціоні, забезпечуючи зростання коефіцієнтів перетравності контрольної і дослідної груп, відповідно нейтрально-детергентної клітковини (38,2 i 46,7 \%), кислото-детергентної клітковини (18,7 і 36,5 \%), суми легкогідролізованих вуглеводів (85,4 і 90,2 \%), гемічелюлози (65,7 і 61,5\%), целюлози (13,2 і 21,4 \%). Рішення щзодо дочільності включення ичелюлозоамілолітичної добавки у склад раціону можна підтвердити на підставі ї̈ використання під час проведення науково-господарського досліду. В контрольній групі середньодобовий приріст живої маси становив 725,07 г, а у дослідній на 19,7 \% більше на рівні 902,53 г. Також відмічено, позитивний вплив на формування біомаси тіла, розвитку окремих органів та їх систем.

Ключові слова: свині, ензими, целюлаза, амілаза, перетравність поживних речовин, інтенсивність росту, продуктивність.

\section{Вступ}

Дані досліджень і аналіз спеціальної літератури свідчить про ефективність використання продуктів мікробіологічного синтезу в годівлі сільськогосподарських тварин. Особливе місце серед них займають ензими (Kononenko, 2017; Kyryliv et al., 2010).

Ензими на відміну від гормонів і біостимуляторів діють не на організм тварин, а лише на компоненти корму у шлунково-кишковому тракті. Вони не накопичуються в організмі та продуктах тваринництва, не входять до складу кінцевих продуктів, не витрачаються в процесі реакції (Hutsol, 2010). Нині відомо велика кількість різних ензимних препаратів, що використовуються в тваринництві. Вони виконують роль біологічних каталізаторів, що багаторазово прискорюють біохімічні реакції (Ndou et al., 2015). Норма споживання ензимів важлива, перенасичення може створювати в шлунково-кишковому тракті желеподібну масу, що перешкоджає утворенню ендогенних травних ферментів і засвоєнню поживних речовин корму.

Целюлаза розщеплює складні вуглеводи (целюлозу та лігнін) на доступний крохмаль. Амілаза розчиняє фракції крохмалю і геміцелюлози, збільшуючи вміст декстринів та глюкози. Це сприяє профілактиці дисбактеріозу, підвищує вироблення власних ферментів, знижуючи розвиток небажаної мікрофлори кишківника (Kostyleva et al., 2017). Ензими амілази та целюлази, сприяють захисту кишкового епітелію, виробляють більше молочної кислоти, що дозволяє підтримувати сприятливий для травлення $\mathrm{pH}$ організму (Emiola et al., 2009; Iulevych et al., 2017). Ефективність засвоєння поживних речовин кормів 3 введенням до раціонів ензимних препаратів на основі амілази та целюлази, позитивно впливають на розвиток корисної мікрофлори шлунково-кишкового тракту, що $є$ важливим в період інтенсивного росту свиней на відгодівлі. Крім перерахованих вище позитивних властивостей, ензими дозволяють знизити навантаження на навколишнє середовище (Silin et al., 2018; Ohorodnichuk, 2016).

Впровадження сучасних технологій в системі годівлі свиней і згодовування комбікормів на свинарських комплексах, вимагає використовувати біологічноактивні добавки - ензими. Використання останніх, в Україні різко відрізняється від провідних країн світу, а отже за рівнем споживання у свинарській галузі $\epsilon$ найвищим (Dekhtiar et al., 2017). У зв'язку з постійним зростанням цін на основні компоненти раціонів і важким засвоєнням вуглеводної сировини рослинного походження актуальним постає використання спеціалізованих ферментних препаратів амілолітичної та целюлозолітичної дії, що застосовуються 3 метою підвищення ефективності використання вуглеводного складу корму (Karunskyi \& Nikolenko, 2017).

В останні роки в країнах Свропи і в інших регіонах створюються і застосовуються в свинарстві численні ензими, які пройшли широку виробничу апробацію і рекомендовані до використання (Tactacan et al., 2016).

Мета $і$ завдання дослідження. Дослідити ефективність використання у раціонах свиней на відгодівлі целюлозоамілолітичної ферментної добавки. Для виконання цієї мети були поставлені наступні завдання:

- дослідити хімічний склад комбікорму;

- дослідити склад і поживність комбікормів свиней на відгодівлі;

- встановити дози споживання різних сумішок ензимів у складі комбікормів піддослідними тваринами;

- визначити продуктивність, затрати на 1 кг приросту, коефіцієнти перетравності для свиней на відгодівлі при використанні ензимів.

\section{Матеріал і методи досліджень}

Ефективність використання целюлозоамілолітичної ферментної добавки, вивчалась у науководослідній роботі, яку проводили в умовах ПФГ “Ясована”, с. Джурин Шаргородського району Вінницької області. Групи свиней формували за методом параналогів, з урахуванням фізіологічного стану, віку, живої маси, інтенсивності росту. Раціон свиней складали на основі норм та поживності кормів, що наводяться у довідниках (Kalashnikov \& Klejmenov, 1985; Provatorov et al., 2008), уточнюючи 3 фактичними даними отриманими під час повного зоотехнічного аналізу кормів, що надійшли у лабораторію оцінки якості, безпеки кормів та сировини. Досліди проводилась на свинях великої білої породи (табл. 1).

Приріст живої маси тварин визначали, користуючись даними індивідуального зважування, яке проводили вранці до годівлі на протязі двох суміжних днів, при закладанні досліду та в кінці зрівняльного і основного періодів, а також щомісячно і після закінчення. 
Таблиця 1

Схема науково-господарського досліду

\begin{tabular}{cccc}
\hline Групи & Кількість & Характеристика раціону & Тривалість досліду, днів \\
\hline тварин, гол. & ОР (63 \% зерно ячменю, 27,5 \% зерно пшениці, & 3рівняльний 15 \\
(контрольна) & 10 & $9 \%$ макуха соєва, 0,5 \% мінеральна добавка) & Основний 71 \\
2 (дослідна) & 10 & ОР + целюлаза 5 г і амілаза 1 г & \\
\hline
\end{tabular}

Приріст живої маси тварин визначали, користуючись даними індивідуального зважування, яке проводили вранці до годівлі на протязі двох суміжних днів, при закладанні досліду та в кінці зрівняльного і основного періодів, а також щомісячно і після закінчення досліду.

Результати досліджень визначили за абсолютним і середньодобовим приростом, затратами кормів на 1 кг приросту. Результати досліджень опрацьовано методом варіаційної статистики за (Plohinskij, 1969) з використанням персонального комп'ютера та програми Statistica 7.0 (Rebrova et al., 2003).

\section{Результати та їх обговорення}

Вплив використання у годівлі свиней ферментної целюлозоамілолітичної кормової добавки у науковогосподарському досліді оцінений за наступними показниками: жива маса свиней на початок і кінець, валовий приріст, середньодобовий приріст, затрати на 1 кг приросту, обмінна енергія, ЕКО.

Вплив досліджуваних чинників під час зрівняльного періоду на інтенсивність росту і розвитку, що наведено у таблиці 2.

Під час зрівняльного періоду, тривалістю 15 діб, спостерігається, що середньодобові прирости тварин двох груп були на рівні 354 г контрольна група та 353 г дослідна група. Відповідність вказує на те що підбір тварин у групах був правильний.

Важливим господарсько-економічним фактором при вирощуванні молодняку свиней на м'ясо, є витрати натурального корму та ЕКО на 1 кг приросту. В основний період досліду в раціоні тварини отримува- ли 3,2 ЕКО 32,3 МДж обмінної енергії та 383,5 г перетравного протеїну.

\section{Таблиця 2}

Продуктивність молодняку свиней за зрівняльний період науково-господарського досліду $(\mathrm{M} \pm \mathrm{m}, \mathrm{n}=4)$

\begin{tabular}{|c|c|c|}
\hline \multirow[b]{2}{*}{ Показник } & \multicolumn{2}{|c|}{ Групи } \\
\hline & $\begin{array}{c}1 \\
\text { (контрольна) }\end{array}$ & $\begin{array}{c}2 \\
\text { (дослідна) }\end{array}$ \\
\hline Жива маса, кг: & & \\
\hline на початок періоду & $49,71 \pm 1,18$ & $49,67 \pm 0,76$ \\
\hline на кінець періоду & $55,02 \pm 1,10$ & $54,97 \pm 0,95$ \\
\hline Тривалість періоду, діб & \multicolumn{2}{|c|}{15} \\
\hline Приріст: & & \\
\hline абсолютний, кг & $5,31 \pm 2,44$ & $5,30 \pm 1,41$ \\
\hline середньодобовий, г & $354 \pm 5,17$ & $353 \pm 4,16$ \\
\hline \pm до контролю, г & & $-1,00$ \\
\hline \pm до контролю, \% & & $-0,28$ \\
\hline
\end{tabular}

Тваринам другої дослідної групи до складу в раціону свиней додавали целюлозоамілолітичну кормову добавку виготовлену з композиції і ензимів у кількості целюлази 5 г і амілази 1 г у перерахунку на 1 кг корму. Приріст молодняку свиней у основний період наведено в таблиці 3, можна підкреслити, що тварини другої дослідної групи, яким ми згодовували целюлозоамілолітичну кормову добавку, мали більший валовий приріст живої маси порівняно до контрольними. Подібні зміни відгодівельних властивостей свиней під дією ензимів свідчать про посилення інтенсивності росту, за рахунок кращого засвоєння кормів.

Таблиця 3

Продуктивність молодняку свиней за основний період науково-господарського досліду $(\mathrm{M} \pm \mathrm{m}, \mathrm{n}=4)$

\begin{tabular}{|c|c|c|}
\hline \multirow{2}{*}{ Показник } & \multicolumn{2}{|c|}{ Групи } \\
\hline & 1 (контрольна) & 2 (дослідна) \\
\hline \multicolumn{3}{|l|}{ Жива маса, кг: } \\
\hline на початок періоду & $55,02 \pm 0,90$ & $54,97 \pm 1,15$ \\
\hline на кінець періоду & $106,5 \pm 4,24$ & $119,05 \pm 3,70^{*}$ \\
\hline Тривалість періоду, діб & 71 & 71 \\
\hline \multicolumn{3}{|l|}{ Приріст: } \\
\hline абсолютний, кг & $51,48 \pm 3,67$ & $64,08 \pm 3,06^{*}$ \\
\hline середньодобовий, г & $725,07 \pm 51,71$ & $902,53 \pm 43,14^{*}$ \\
\hline \pm до контролю, г & - & 177,46 \\
\hline 士 до контролю, \% & - & 19,66 \\
\hline Витрати корму на 1 кг приросту, ЕКО & 3,3 & 3 \\
\hline 士 до контролю, ЕКО & - & $-0,3$ \\
\hline \pm до контролю, \% & - & -10 \\
\hline
\end{tabular}

Примітка: ${ }^{*}-\mathrm{P}>0,05,{ }^{* *}-\mathrm{P}>0,01-$ статистична вірогідність порівняно 3 контролем 
У дослідних тварин вірогідно збільшується жива маса $(\mathrm{P}<0,05)$, абсолютний приріст $(\mathrm{P}<0,05)$, середньодобовий приріст $(\mathrm{P}<0,05)$. Важливим господарсько-економічним фактором при вирощуванні молодняку свиней на м'ясо, є витрати натурального корму та ЕКО на 1 кг приросту. Таким чином, дослідна група, що споживала ферментну целюлозоамілолітичну кормову добавку, мала нижчу конверсію корму на $10 \%$ порівняно 3 контролем. Середньодобовий приріст контрольних і дослідних тварин відмічений на високому рівні, 725 і 902 г відповідно, зростаючи на 177,46 г або у відсотках 19,7 \%.

\section{Висновки}

1. На основі експериментальних досліджень доведено, що підвищення продуктивності свиней на відгодівлі за сучасних господарсько-економічних умов може забезпечуватися використанням у їх годівлі добавки кормової ферментної целюлозоамілолітичної, якій властива висока активність розщеплення структурних вуглеводів корму, ферментолізу в слизовій оболонці кишечнику, покращеному засвоєнню вуглеводів та основних поживних речовин, що забезпечує інтенсивний ріст тварин та одержання якісної продукції тваринництва.

2. За згодовування молодняку свиней на відгодівлі добавки кормової ферментної целюлозоамілолітичної, одержані порівняно кращі відгодівельні показники за дози 5 г целюлази і 1 г амілази на 1 кг корму - середньодобові прирости під час науковогосподарського досліду збільшувались на 177,46 г, або на 19,7 \%; при зменшенні витрат корму на 1 кг приросту на $10 \%$.

Перспективи подальших досліджень. Застосування у годівлі свиней нових ензимів, вироблених 3 вітчизняної сировини. Аналіз впливу добавки кормової ферментної целюлозоамілолітичної у дозуванні 5 г целюлази і 1 г амілази в перерахунку на 1 кг корму покращує продуктивні, поживні, клінічні, морфологічні, імунологічні показники свиней, що потребує подальшого вивчення.

\section{References}

Dekhtiar, Yu. F., Barkar, Ye. V., \& Bohomaz, A. V. (2017). Efektyvnist vykorystannia fermentnoho preparatu Vilzim v ratsionakh molodniaku svynei na doroshchuvanni i vidhodivli. Molodyi vchenyi, 12(52), 24-27. URL: http://molodyvcheny.in.ua/ files/journal/2017/12/6.pdf (in Ukrainian).

Emiola, I. A., Opapeju, F. O., Slominski, B. A., \& Nyachoti, C. M. (2009). Growth performance and nutrient digestibility in pigs fed wheat distillers dried grains with solubles-based diets supplemented with a multicarbohydrase enzyme. J. Anim. Sci., 87(7), 2315-2322. doi: 10.2527/jas.2008-1195.

Hutsol, A. V. (2010). Eksperymentalne obgruntuvannia efektyvnosti vykorystannia fermentnykh prepa-rativ ta yikh kompozytsii v hodivli svynei: avtoref. dys. d-ra s.-h. nauk: 06.02.02 LNUVMtaB imeni S.Z. Gzhytskoho (in Ukrainian).
Iulevych, O. I., Lykhach, A. V., \& Dekhtiar, Yu. F. (2017). Efektyvnist vykorystannia probiotykiv u hodivli pomisnykh porosiat na doroshchuvanni. Naukovyi visnyk LNUVMBT imeni S.Z. Gzhytskoho, 19(74), 91-94. doi: 10.15421/nvlvet7420 (in Ukrainian).

Kalashnikov, A. P., \& Klejmenov, N. I. (1985). Normy i raciony kormlenija sel'skohozjajstvennyh zhivotnyh: spravochnoe posobie. M.: Agropromizdat (in Russian).

Karunskyi, O. Y., \& Nikolenko, I. V. (2017). Vplyv fermentnoho preparatu "Lizotsym" na pokaznyky krovi ta produktyvnist svynei. Ahrarna nauka ta kharchovi tekhnolohii, 3(97), 52-58. URL: http://nbuv.gov.ua/UJRN/anxt_2017_3_9 (in Ukrainian).

Kononenko, S. I. (2017). Povyshenie jeffektivnosti kormlenija svinej za schet ispol'zovanija fermen-tov. Agrarnaja nauka v uslovijah modernizacii i innovacionnogo razvitija, 278-282. https://cyberleninka.ru/article/n/fermentnyy-preparatv-kormlenii-sviney (in Russian).

Kostyleva, E., Velikoreckaja, I., Sereda, A., Curikova, N., Betin, A., \& Sinicyn, A. (2017). Kompleksnyj fermentnyj preparat $\mathrm{v}$ zernobobovyh racionah svinej. Kombikorma, 9, 98-100. https://elibrary.ru/item.asp ?id=29935519 (in Russian).

Kyryliv, Ya. I., \& Hutsol, A. V. (2010). Peretravnist kormu ta obminu azotu u molodniaku svynei pry zghodovuvanni minazy. Naukovyi visnyk LNUVMtaB imeni S. Z. Gzhytskoho, 12, 2(44), 8486. https://nvlvet.com.ua/index.php/food/issue/view/ 129/12-2-2010-pdf (in Ukrainian).

Kyryliv, Ya. I., Hutsol, A. V., \& Bolokhovskyi, V. V. (2010). Vykorystannia fermentnykh preparativ vitchyznianoho vyrobnytstva v hodivli svynei. Metodychni rekomendatsii. LNUVMtaB imeni S.Z. Gzhytskoho, Lviv (in Ukrainian).

Ndou, S. P., Kiarie, E., Agyekum, A. K., Heo, J. M., Romero, L. F., Arent, S., Lorentsen, R., \& Nyachoti, C. M. (2015). Comparative efficacy of xylanases on growth performance and digestibility in growing pigs fed wheat and wheatbran-cornand corn DDGS-based diets supplemented with phytase. Anim. Feed Sci. Technol., 209. 230-239. doi: 10.1016/j.anifeedsci.2015.08.011.

Ohorodnichuk, H. M. (2016). Efektyvnist vykorystannia fermentnykh preparativ i kormovoi dobavky PKD-10 v hodivli svynei. Naukovyi visnyk LNUVMBT imeni S.Z. Gzhytskoho, 18, 2(67), 163-167. doi: 10.15421/nvlvet6737 (in Ukrainian).

Plohinskij, N. A. (1969). Rukovodstvo po biometrii dlja zootehnikov. Moskva: Kolos (in Russian).

Provatorov, H. V., Ladyka, V. I., \& Bondarchuk, L. V. (2008). Normy hodivli, ratsiony i pozhyvnist kormiv riznykh vydiv silskohospodarskykh tvaryn: dovidnyk. ta in. Sumy: Universytetska knyha (in Ukrainian).

Rebrova, O. Ju. (2003). Statisticheskij analiz medicinskih dannyh. Primenenie paketa prikladnyh programm STATISTICA. M.: Media Sfera (in Russian).

Silin, M. A., Nekrasov, R. V., \& Chabaev, M. G. (2018). Vlijanie skarmlivanija kombikormov, obogashhjonnyh fermentnymi preparatami, na produktivnost' i obmen 
veshhestv u otkarmlivaemogo molodnjaka svinej. Problemy biologii produktivnyh zhivotnyh, 1, 83-93. doi: 10.25687/1996-6733.prodanimbiol.2018.1.83-93 (in Russian).

Tactacan, G. B., Cho, S.-Y., Cho, J. H., \& Kim, I. H. (2016). Performance responses, nutrient digestibility, blood characteristics, and measures of gastrointestinal health in weanling pigs fed protease enzyme. AsianAustral. J. Anim. Sci., 29(7), 998-1003. doi: 10.5713/ajas.15.0886. 